\title{
Preventing Foodborne Illness: E. coli 0157:H7
}

\section{Keith R. Schneider, Renée Goodrich Schneider, Alexandra Chang, and Susanna Richardson²}

This is one in a series of fact sheets discussing common foodborne pathogens of interest to food handlers, processors, and retailers. For related publications, visit http://edis.ifas. ufl.edu/topic_foodborne_illness.

\section{What Causes an E. coli 0157:H7- associated Foodborne Illness?}

Escherichia coli or E. coli is a bacterium from the family Enterobacteriaceae usually found in the digestive system of healthy humans and animals and transmitted through fecal contamination. ${ }^{1,15}$ There are hundreds of known $E$. coli strains, with E. coli O157:H7 being the most recognized. ${ }^{3}$ This enterohemorrhagic E. coli (or EHEC) strain is responsible for an estimated 63,153 cases of infection and 20 deaths in the United States annually, and causes approximately $\$ 255$ million in losses each year. ${ }^{7}$ E. coli are found everywhere in the environment but mostly occupy animal surfaces and digestive systems, making it important to thoroughly wash anything that comes into contact with these surfaces. ${ }^{1,15}$

\section{Outbreaks Associated with E. coli 0157:H7}

The most recent $E$. coli O157:H7 outbreak reported by the CDC was during the fall of 2012. This outbreak was tentatively traced to pre-packaged leafy greens. As of July 2013, 33 people became ill, with two people developing hemolytic uremic syndrome (HUS). However, no deaths were reported. ${ }^{3}$

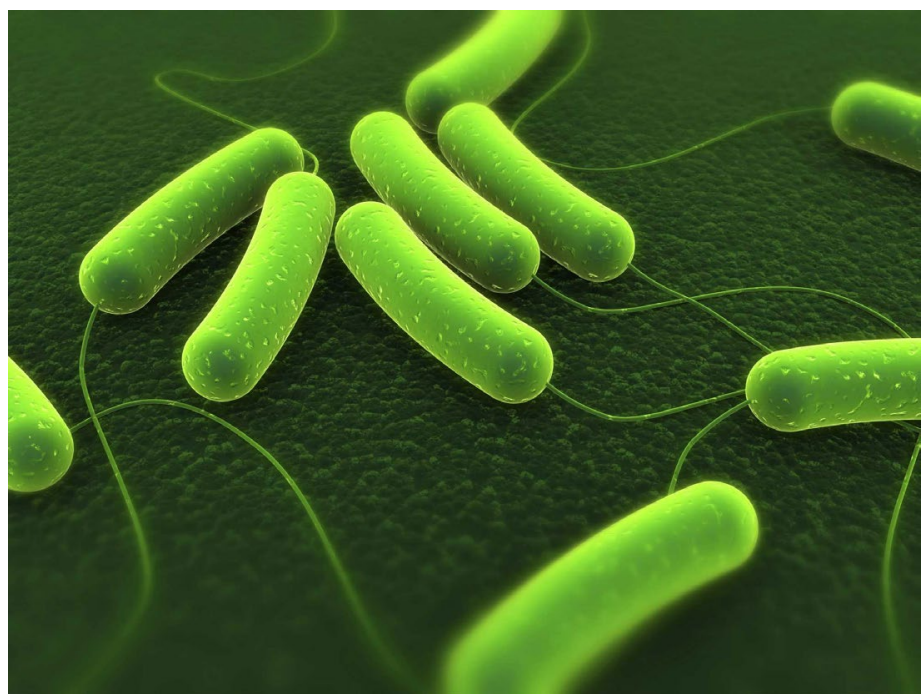

Lettuce and other leafy greens have been common facilitators of E. coli O157:H7 in recent years. One of the largest outbreaks of $E$. coli O157:H7 was associated with fresh spinach in 2006. Almost 200 people in 26 states were sickened, 31 developed HUS, and three people died. ${ }^{3}$

E. coli O157:H7 outbreaks are not limited to a particular type of food product. In the last six years, there have been outbreaks associated with meats (cooked and raw), lettuce, cheese, nuts, pizza, and even cookie dough. This widespread contamination has caused a large push in the scientific community to determine precisely how E. coli $\mathrm{O} 157: \mathrm{H} 7$ is perpetuated.

1. This document is FSHN031, one of a series of the Food Science Human Nutrition Department, UF/IFAS Extension. Original publication date: January 2003. Latest revision: October 2013. Visit the EDIS website at http://edis.ifas.ufl.edu.

2. Keith R. Schneider, professor, Food Science and Human Nutrition Department; Renée Goodrich Schneider, associate professor, Food Science and Human Nutrition Department; Alexandra Chang, food microbiologist, Land O' Lakes, St. Paul, Minnesota; and Susanna Richardson, laboratory technician, Food Science and Human Nutrition Department; UF/IFAS Extension, Gainesville, FL 32611. 


\section{What Type of Bacterium Is E. coli 0157:H7?}

E. coli $\mathrm{O} 157: \mathrm{H7}$ are Gram-negative rods that have been variously described as verotoxigenic E. coli (VTEC) or shiga-like toxin producing E. coli (SLTEC). Most recently, the designation has been simplified to shiga-toxin producing E. coli (STEC) in recognition of the similarities of the toxins produced by E. coli O157:H7 and Shigella dysenteriae. ${ }^{4,11}$ These potent toxins are the cause of severe damage to the intestinal lining of those infected. The toxins produced by $E$. coli $\mathrm{O} 157: \mathrm{H} 7$ are responsible for the symptoms associated with infection such as hemorrhagic colitis, HUS, and even death. ${ }^{4}$ The organism can survive at low temperatures and under acidic conditions, making it difficult to eradicate in nature. ${ }^{12}$ The organism has a low infective dose and can be transmitted from person to person, as well as in food products. ${ }^{2}$

\section{How Is the E. coli 0157:H7 Bacterium Spread?}

Sources of E. coli O157:H7 infections include undercooked or raw hamburgers, sheep, pigs, goats, poultry, game meat, alfalfa sprouts, unpasteurized fruit juices, dry-cured salami, lettuce, cheese curds, unpasteurized or raw milk, contaminated water and ice, and person-to-person transmission. ${ }^{1,8,14}$ Fruits and vegetables can cause infection from contact with contaminated water. The most common source of infection, however, is caused by consuming undercooked or raw meats. ${ }^{1,15}$ Because there appears to be a low infective dose for this organism (10-100 cells), adequate sanitation and/or proper processing of foods is critically important. ${ }^{10}$

\section{Symptoms of E. coli 0157:H7 Infection}

The acute disease associated with this organism is named hemorrhagic colitis. The symptoms characteristic to this disease are watery and/or bloody diarrhea, fever, nausea, severe abdominal cramping, and vomiting. ${ }^{4,13}$ Because most people recover from this infection on their own, treatment is usually not necessary. Symptoms can appear within hours or up to several days after ingestion of the bacteria, and the illness usually lasts 5-10 days. Some individuals may develop HUS. In the very young, this disorder can cause renal failure, hemolytic anemia, or even permanent loss of kidney function. ${ }^{4,13}$ In the elderly, these symptoms may occur, as well as thrombotic thrombocytopenic purpura (TTP) (HUS with additional neurological dysfunction and/ or fever) ${ }^{13}$

\section{High-risk Populations for E. coli 0157:H7 Infections}

E. coli $\mathrm{O} 157: \mathrm{H} 7$ infection can be serious for healthy people of any age, but it is more likely to cause severe illness in the very young (under age five), the elderly, and immunocompromised patients. ${ }^{13}$ There is also a higher risk of infection for workers in certain industries; those working in slaughterhouses, farms, hospitals, nursing homes, nursery schools, and food preparation locations are more susceptible to infection than the rest of the population. ${ }^{8}$

\section{Minimizing the Risk of $E$. coli 0157:H7 in Plants or Food Establishments Sanitation Methods \\ CLEAN}

Use hot, soapy water and a sanitizer to wash hands and surfaces that contact food often. Wash hands, cutting boards, dishes, and utensils after they come in contact with raw food. Clean liquid spills in the refrigerator, especially spills from products associated with $E$. coli.

- Ensure employees wash hands before, during, and after handling any food, particularly raw meat and poultry.

- Sanitize all utensils, cutting boards, and work surfaces before and after use, using an approved sanitizing agent.

- Clean food contact surfaces, such as refrigerator shelving, if they come in contact with possible sources of $E$. coli contamination.

- Wash all vegetables and fruits thoroughly before consumption.

\section{SEPARATE}

Treat all RTE (ready-to-eat) foods, raw meat, poultry, and seafood as possible sources of contamination. Keep these foods separate from items that traditionally do not get cooked or potentially can be eaten raw, such as vegetables, fruits, breads, and other already-prepared, edible foods.

This reduces the chance of cross-contamination.

- Use separate utensils for raw and cooked foods.

- Store meats and other potential sources of contamination in areas below foods that may be consumed raw.

- Rewrap open packages carefully or store in leakproof containers to prevent cross-contamination. 


\section{COOK}

Heat foods to safe temperatures. The 2009 FDA Food Code recommends cooking to an internal temperature of $165^{\circ} \mathrm{F}$ or above for 15 seconds for most potentially hazardous foods (refer to Sections 3-4: Destruction of Organisms of Public Health Concern, Subparts 3-401 and 3-501 for specific details on cooking temperatures). ${ }^{6}$

At the present time, the best measures to control E. coli are proper cooking, preventing cross-contamination of raw and cooked food, proper personal hygiene, and good sanitation. Follow these recommendations to reduce the incidence of foodborne E. coli contamination:

- Don't store food in the temperature danger zone between $41^{\circ} \mathrm{F}\left(5^{\circ} \mathrm{C}\right)$ and $135^{\circ} \mathrm{F}\left(57^{\circ} \mathrm{C}\right) .^{6}$ The refrigerator should be at $39.2^{\circ} \mathrm{F}\left(4^{\circ} \mathrm{C}\right)$ or colder. All food should be refrigerated promptly. ${ }^{6}$

- Completely cook or boil foods such as hot dogs and poultry products until they become steaming hot $\left[165^{\circ} \mathrm{F}\right.$ $\left(73.8^{\circ} \mathrm{C}\right)$ or above].

\section{STORAGE}

Limit the amount of time food is exposed to room temperature to two hours or less before returning perishables and RTE foods to the refrigerator or freezer.

- Cover all food to prevent cross-contamination.

- Place all cooked food in the refrigerator within one hour of cooking.

- Place uncooked meat, poultry, fish, or other raw products below cooked or RTE foods in the refrigerator to prevent cross-contamination.

- Maintain the refrigerator temperature at or below $39.2^{\circ} \mathrm{F}$ $\left(4^{\circ} \mathrm{C}\right)$, and keep refrigerator clean.

- Follow the "use by" or "best by" dates on refrigerated items.

\section{Good Practices for Food Product Receiving, Handling, Processing, and Storage}

The FDA defines current Good Manufacturing Practices for food (cGMPs) in title 21 of CFR (Code of Federal Regulations) part $110 .{ }^{5}$ These cGMPs outline the minimum required general sanitation practices in FDA-inspected food handling and processing facilities. It is recommended that more specific and stringent standard operating procedures (SOPs) be developed for individual facilities. In addition, the sanitation recommendations for food service and retail food facilities outlined in the FDA Food Code have been adopted into many state and local regulations. ${ }^{6}$ Because of the variation in Food Code adoption, each facility should check with the appropriate state and/or local regulatory authority. The Florida Statutes can be found online at http:// www.leg.state.fl.us/statutes/. Title 33, Chapter 509 specifies some of these regulations.

In addition to setting and following strict sanitation requirements in the facility, a retail establishment should also develop SOPs for receiving and storing food products and ingredients. If food processing is being done, appropriate controls and requirements should be established and strictly followed. The FDA Food Code outlines appropriate processing and cooking requirements for many food products processed in a retail facility. However, if a retail establishment processes certain high-risk food products (e.g., sushi, fresh juice, specialty meats, and others), additional controls and the issuance of a "variance" by the regulatory authority is required before processing can occur. $^{6}$ The growing retail practice of cooking/preparing/ packaging foods traditionally processed in controlled plant environments raises safety concerns. Any processing of food at the retail level needs to be closely monitored.

As an establishment becomes cleaner, it becomes harder to detect foodborne pathogens. At this point, testing becomes more limited in its ability to prevent foodborne illness. This is why programs that promote and monitor the use of barriers and/or hurdles are so important. When instituted properly, these activities reduce the risk of foodborne illness. Nothing can be done to completely eliminate bacterial contamination short of irradiation. Since most consumers prefer a fresh product, programs should be implemented that reduce the probability of illness to a point that it is minuscule.

\section{Receiving}

Specifications for receiving can be found in Section 3-202.11 of the 2009 Food Code. ${ }^{6}$ The following guidelines cover the basic points that should be addressed:

- Potentially Hazardous Food (PHF) should be at $41^{\circ} \mathrm{F}$ $\left(5^{\circ} \mathrm{C}\right)$ or below when received, unless specified by law (e.g., milk, shellfish).

- Raw shell eggs should be received at an ambient air temperature of $44.6^{\circ} \mathrm{F}\left(7^{\circ} \mathrm{C}\right)$ or less.

- PHFs received hot should be at a temperature of $140^{\circ} \mathrm{F}$ $\left(60^{\circ} \mathrm{C}\right)$ or above.

- PHF should be received with no evidence of temperature abuse such as evidence of thawing. 


\section{Processing}

One of the easiest ways to prevent foodborne salmonellosis is ensuring that foods are cooked thoroughly. It should be noted that certain foods typically served uncooked-raw eggs (used in Caesar salads, homemade mayonnaise, raw cookie dough, etc.) and fresh vegetables-would obviously not benefit from the cooking process. For these items, other factors such as sanitation, worker hygiene, and proper storage take on much greater importance.

- When using raw eggs in your recipes, purchase a pasteurized egg product.

- Cook eggs, fish, meat, or foods containing these items to an internal temperature of $145^{\circ} \mathrm{F}\left(62.7^{\circ} \mathrm{C}\right)$ or above for a minimum of 15 seconds.

- Cook ground meat products to an internal temperature of $155^{\circ} \mathrm{F}\left(68.3^{\circ} \mathrm{C}\right)$ or above for a minimum of 15 seconds.

- Cook poultry to an internal temperature of $165^{\circ} \mathrm{F}$ $\left(73.8^{\circ} \mathrm{C}\right)$ or above for a minimum of 15 seconds.

- Reheat previously cooked material to an internal temperature of $165^{\circ} \mathrm{F}\left(73.8^{\circ} \mathrm{C}\right)$.

\section{Storage}

Once a product has been received and/or processed, it now will be displayed or stored. There are some general guidelines governing these practices as well.

- Frozen food should remain frozen until it is used.

- If frozen food is displayed in a refrigerated case, the food should remain at $41^{\circ} \mathrm{F}\left(5^{\circ} \mathrm{C}\right)$ or below.

- Frozen food should be thawed at a temperature of $41^{\circ} \mathrm{F}$ $\left(5^{\circ} \mathrm{C}\right)$ or below. Food can also be thawed under running water at a temperature of $69.8^{\circ} \mathrm{F}\left(21^{\circ} \mathrm{C}\right)$ or below. Lastly, the product can be thawed as part of the cooking process.

- The product must be cooled adequately. Refer to sections 3-501.14 and 3-501.15 of the 2009 Food Code.

- Hold cooked product above $140^{\circ} \mathrm{F}\left(60^{\circ} \mathrm{C}\right)$ while displaying, and under $41^{\circ} \mathrm{F}\left(5^{\circ} \mathrm{C}\right)$ while storing.

- Properly label all stored product. ${ }^{6}$

\section{Personal Hygiene}

Wash your hands! The major cause of foodborne illness in retail establishments comes from poor personal hygiene, particularly a lack of proper hand washing. Dirty hands can contaminate food. Although hands may look clean, the bacteria that cause illness are too small to be seen. Whenever you are preparing food and come in contact with items that are not part of the assembly process, rewash your hands. The same is true even when wearing gloves. There is no five-second rule when it comes to food safety! Millions of bacteria and other germs can be transferred on contact.

You should wash your hands in the following situations:

- Before handling, preparing, or serving food

- Before handling clean utensils or dishware

- After using the restroom

- After touching your face, cuts, or sores

- After smoking, eating, or drinking

- After handling raw meat, especially poultry

- After touching unclean equipment, working surfaces, soiled clothing, soiled wiping cloths, etc.

- After collecting and/or taking out the garbage

Your facility may have even stricter requirements you must comply with to ensure food safety.

\section{What Is the Proper Procedure for Hand Washing?}

1. Wet your hands with warm water.

2. Apply soap and wash your hands for 20 seconds.

3. Rinse and dry with a single-use paper towel.

4. Use the paper towel to shut off the water.

\section{Resources}

"Current Good Manufacturing Practice in Manufacturing, Packing, or Holding Human Food," Title 21 Code of Federal Regulations, Pt. 110. 2009 ed. Accessed February 2013. http://www.access.gpo.gov/nara/cfr/ waisidx_09/21cfr110_09.html.

"Regulation of Trade, Commerce, Investments, and Solicitations: Lodging and Food Service Establishments," Title 33 Florida Statutes, ch. 509. 2012. Accessed January 2013. http://www.leg.state.fl.us/statutes/.

U.S. Food and Drug Administration. 2012. Bad Bug Book: Escherichia coli O157:H7. Washington, D.C.: U.S. Department of Health and Human Services, Food and Drug Administration. http://www.fda.gov/food/foodborneillnesscontaminants/causesofillnessbadbugbook/default.htm.

Brown, J. C. 1995. What the Heck Is an E. coli? [Internet]. Lawrence, KS: University of Kansas. http://people.

ku.edu/\%7Ejbrown/ecoli.html 


\section{References}

1. G. L. Armstrong, J. Hollingsworth, and J. G. Morris, Jr., "Emerging Foodborne Pathogens: Escherichia coli O157:H7 as a Model of Entry of a New Pathogen into the Food Supply of the Developed World," Epidemiologic Reviews 18, no. 1 (1996): 29-51.

2. T. E. Besser, B. L. Richards, D. H. Rice, and D. D. Hancock, "Escherichia coli O157:H7 Infection of Calves: Infectious Dose and Direct Contact Transmission," Epidemiology and Infection 127 (2001): 555-560.

3. Centers for Disease Control and Prevention, "E. coli (Escherichia coli)," National Center for Emerging and Zoonotic Infectious Diseases, Division of Foodborne, Waterborne, and Environmental Diseases, last modified January 4, 2013, http://www.cdc.gov/ecoli/.

4. C. L. Fischer Walker, J. A. Applegate, and R. E. Black, "Haemolytic-Uraemic Syndrome as a Sequela of Diarrhoeal Disease," Journal of Health, Population and Nutrition 30, no. 3 (2012): 257-261.

5. Food and Drug Administration, Code of Federal Regulations Title 21-Part 110. (Silver Spring, MD: Department of Health and Human Services, 2012), http://www.accessdata.fda.gov/scripts/cdrh/cfdocs/ cfcfr/CFRSearch.cfm?CFRPart=110\&showFR=1.

6. Food and Drug Administration. FDA 2009 Food Code - Table of Contents. [Online], 2009. http://www.fda. gov/Food/GuidanceRegulation/RetailFoodProtection/ FoodCode/UCM2019396.htm.

7. S. Hoffmann, M. B. Batz, and J. G. Morris, Jr., "Annual Cost of Illness and Quality-Adjusted Life Year Losses in the United States due to 14 Foodborne Pathogens," Journal of Food Protection 75, no. 7 (2012): 1292-1302.

8. H. D. Kassenborg, C. W. Hedberg, M. Hoekstra, M. C. Evans, A. E. Chin, R. Marcus, D. J. Vugia, K. Smith, S. D. Ahuja, L. Slutsker, and P. M Griffin, for the Emerging Infections Programs FoodNet Working Group, "Farm Visits and Undercooked Hamburgers as Major Risk Factors for Sporadic Escherichia coli O157:H7 Infection: Data from a Case-Control Study in 5 FoodNet Sites," Clinical Infectious Diseases 38, Suppl. 3 (2004): S271-278.

9. W. E. Keene, J. M. McAnulty, F. C. Hoesly, L. P. Williams, Jr., K. Hedberg, G. L. Oxman, T. J. Barrett, M. A. Pfaller, and D. W. Fleming. "A Swimming-Associated
Outbreak of Hemorrhagic Colitis Caused by Escherichia Coli O157:H7 and Shigella Sonnei," The New England Journal of Medicine 331, no. 9 (1994): 579-584.

10. E. C. Mathusa, Y. Chen, E. Enache, and L. Hontz. "NonO157 Shiga Toxin-Producing Escherichia coli in Foods," Journal of Food Protection 73, no. 9 (2010): 1721-1736.

11. P. R. Murray, E. J. Baron, J. H. Jorgensen, M. L. Landry, and M. A. Pfaller (Eds.), Manual of Clinical Microbiology, 9th ed. (Washington: ASM Press, 2007).

12. J. C. Paton, and A. W. Paton. "Pathogenesis and Diagnosis of Shiga Toxin-Producing Escherichia coli Infections," Clinical Microbiology Reviews 11, no. 3 (1998): 450-479.

13. P. I. Tarr, "Escherichia coli O157:H7: Clinical, Diagnostic, and Epidemiological Aspects of Human Infection," Clinical Infectious Diseases 20, no. 1 (1995): 1-8.

14. J. Tilden, Jr., A. McNamara, C. Custer, B. Boesel, M. A. Lambert-Fair, J. Majkowski, D. Vugia, S. B. Werner, J. Hollingsworth, and J. G. Morris, Jr., "A New Route of Transmission for Escherichia coli: Infection from Dry Fermented Salami," American Journal of Public Health 86, no. 8 (1996): 1142-1145.

15. J. Tuttle, T. Gomez, M. P. Doyle, J. G. Wells, T. Zhao, R. V. Tauxe, and P. M. Griffin, "Lessons from a Large Outbreak of Escherichia coli O157:H7 Infections: Insights into the Infectious Dose and Method of Widespread Contamination of Hamburger Patties." Epidemiology and Infection 122 (1999): 185-192. 